REPORTS OF MORPHOLOGY
Official Journal of the Scientific Society of Anatomists,
Histologists, Embryologists and Topographic Anatomists
of Ukraine
journal homepage: https://morphology-journal.com

\title{
Peculiarities of girth body sizes in men with mild and severe psoriasis course
}

Obadeh Bassam Abdel-Rahman Al-Qaraleh ${ }^{1}$, Dmytrenko S. V. ${ }^{1}$, Shayuk A. V. ${ }^{2}$, Gunas I. V. ${ }^{1}$, Prokopenko S.V. ${ }^{1}$ National Pirogov Memorial Medical University, Vinnytsya, Ukraine

2Zhytomyr Ivan Franko State University, Zhytomyr, Ukraine

\section{ARTICLE INFO}

Received: 21 September, 2020

Accepted: 26 October, 2020

UDC: 616.517 .8

\section{CORRESPONDING AUTHOR}

e-mail: svetlana7783@ukr.net Dmytrenko S.V.
Given the most frequent manifestation of psoriasis at a young working age and in some cases severe, continuously recurrent course, the presence of many treatments, none of which is a guarantee of complete recovery and no recurrence - now there is an urgent need to find prognostic signs therapy and prevention of relapses. In the absence of ideal biomarkers, the study of constitutional markers becomes crucial. The aim of the study was to examine the differences in girth body sizes between healthy and/or psoriatic men depending on the severity of the disease. Anthropometric examination according to V.V. Bunak was performed for 32 men of the first mature age patients with mild and 68 with severe psoriasis course. The PASI index was used to clinically assess the severity and area of psoriatic lesions. The control group, according to anthropometric parameters, consisted of 82 practically healthy men of the same age, selected from the database of the research center of National Pirogov Memorial Medical University, Vinnytsya. Statistical data processing was performed in the license package "Statistica 5.5" using non-parametric methods of evaluation of the obtained results. In patients with psoriasis of mild and severe course, compared with healthy, we found: greater values for - the girth of the shoulder in a tense state by $8.9 \%$ and $6.8 \%$; shoulder girth in the unstressed state by $14.2 \%$ and $12.3 \%$; forearm girth in the upper part by $8.0 \%$ and $7.1 \%$; forearm girth in the lower part by $4.2 \%$ and $4.5 \%$; hand girth by $5.1 \%$ and $5.8 \%$; hip girth by $11.4 \%$ and $9.3 \%$; hips circumference by $8.7 \%$ and $6.5 \%$; crus girth in the upper part by $10.2 \%$ and $7.9 \%$; crus girth in the lower part by $8.7 \%$ and $5.9 \%$; neck girth by $6.9 \%$ and $7.8 \%$; waist circumference by $17.1 \%$ and $18.2 \%$; chest girth on inspiration by $7.8 \%$ and 7.2\%; chest girth on exhalation by $10.6 \%$ and $10.3 \%$; chest circumference at rest by $10.0 \%$ and $9.6 \%$. Thus, there are pronounced differences in the girth sizes between healthy and patients with mild and severe psoriasis Ukrainian men of the first mature age. Between patients with varying degrees of severity of dermatosis, differences are established only for the girth of the crus in the lower part.

Keywords: psoriasis, girth body sizes, men.

\section{Introduction}

More than 200 years have passed since the first detailed description of psoriasis by Robert Willan, the "father" and founder of modern dermatovenereology, but humanity still has no effective treatment for this disease, which causes a deterioration in the quality of life of patients [6].

The prevalence of psoriasis is heterogeneous in different parts of the world and within the same country and different age groups. Thus, in northern India, psoriasis affects between 0.44 and $2.8 \%$ of the adult population. The peak of the disease occurs at the age of 6-10 years in boys and 11-15 years in girls [6].

Scientists estimate that psoriasis affects approximately 125 million people worldwide. Taiwan and the United States are considered to be the countries with the low prevalence of psoriasis, where the prevalence of this disease among the adult population is $0 \%$ and $0.91 \%$, respectively; examples of countries with a high prevalence of psoriasis are Italy and Norway, where the figure is about $2.1 \%$ and $8.5 \%$, respectively $[10,18]$. The prevalence of psoriasis among children in the United States is 40.8 per 100 thousand people/year, among adults - 78.9 per 100 thousand people/year, while in Italy the figure is 230 per 100 thousand people/year [18].

Given these facts, in the last decade there has been an increase in the number of works on the search for markers that would help determine the risk and severity of psoriasis, and in this aspect, special attention should be paid to the 
relationship between these phenomena and such markers as body size of human [2, 4, 11, 26, 27].

Ferguson L. D. and co-authors [8] conducted an anthropometric survey of more than 500 thousand people aged 40-70 years, of which 5074 people suffered from psoriasis. In order to identify the relationship between certain anthropometric indicators and the chance of psoriasis, a statistical analysis of the data was performed. The adjusted odds ratios $(\mathrm{OR})$ for psoriasis were according to the standard deviation $(13.5 \mathrm{~cm})$ : the highest waist circumference was 1.20 $(95 \% \mathrm{Cl} 1.16,1.23)(\mathrm{p}<0.001)$. This OR remained significant after further adjustment according to body mass index in patients with psoriasis (OR $1.19(95 \% \mathrm{Cl} 1.12,1.27))(p<0.001)$.

An anthropometric study was performed on 135 children with psoriasis of varying severity and 73 healthy children (control group). Significantly higher prevalence of weight-toheight ratio (WHR) of 0.5 and more in children with psoriasis compared with the control group $(p=0.002)$. OR with WHR more than 0.5 in children with psoriasis compared with the control group was 3.30 (95\% Cl 1.45-7.52). However, researchers have not found a significant difference in the rate of WHR in different forms of psoriasis. Only in children with moderate and severe forms of psoriasis, the average rate of WHR was higher than in children with mild psoriasis $(0.48$ vs. $0.46, p=0.04)$ [13]. Plasma adiponectin levels, insulin resistance, waist circumference, and psoriasis have been found to be related [14].

The authors' analysis of 1259 literature sources, 17 of which were selected for meta-analysis, revealed that there is a statistically significant relationship between the occurrence of psoriasis in childhood and WHR, if it is more than 0.5 [19].

A group of Norwegian scientists conducted two examinations of 34,996 people, without psoriasis in 19951997 and 2006-2008, in order to identify the risks of this disease. Between examinations, in 374 people developed psoriasis. Statistical analysis of the data revealed that there is a relationship between body mass index (BMI) and waist circumference and the risk of psoriasis [21]. One standard deviation, such as higher body mass index, waist circumference, and waist-to-hip ratio, gave a relative risk of 1.22 (95\% confidence interval $(\mathrm{Cl}=1.11-1.34), 1.26(95 \% \mathrm{Cl}=$ $1.15-1.39)$, and $1.18(95 \% \mathrm{Cl}=1.07-1.31)$ respectively [22].

Similar results were obtained in another study. The examined children with psoriasis had higher BMI (?85th percentile; OR $4.4 ; 95 \% \mathrm{Cl} 1.2-15.6)$, waist circumference (>75th percentile; OR $7.4 ; 95 \% \mathrm{Cl} 2.0-27.7$ ) and waist-to-height ratio (>0.490; OR 4.6; 95\% Cl 1.3-17.0) [24].

The aim of the study was to found the differences in girth body sizes between healthy and/or psoriatic men depending on the severity of the disease.

\section{Materials and methods}

Men aged 22 to 35 years, patients with psoriasis ( $\mathrm{n}=$ 100, including 32 with mild and 68 with severe course) at the Department of Skin and Venereal Diseases with a course of postgraduate education at National Pirogov Memorial
Medical University, Vinnytsya and the Military Medical Clinical Center of the Central region, an anthropometric examination was conducted according to V.V. Bunak [3].

The PASI (Psoriasis Area and Severity Index) was used to clinically assess the severity and area of psoriatic lesions [9]. According to the scoring system, the intensity of erythema, infiltration and peeling was determined: 0 points - no symptom, 1 - mild, 2 - moderate, 3 - severe, 4 - very severe. The following formula was used to calculate the PASI index for each body area: the anatomical area of the body (for the head -0.1 , the upper extremities -0.2 , the torso -0.3 , the lower extremities - 0.4) $\times$ (severity of erythema + severity of infiltration + severity of peeling) $x$ area of skin lesions of the corresponding anatomical region of the body. Assessment of the severity of psoriasis was performed on the total PASI index (the sum of the obtained indices for each body area): mild - PASI<10; medium degree - PASI values from 10 to 20; severe - PASI>20 [1].

The control group consisted of anthropometric data of 82 practically healthy men of the same age group from the data bank of the research center of National Pirogov Memorial Medical University, Vinnytsya.

In this study, an assessment of the circumferential size of the body $(\mathrm{cm})$ done. Statistical processing was performed in the license package "Statistica 5.5" using non-parametric evaluation methods. The reliability of the difference between the values between the independent quantitative values was determined using the Mann-Whitney U-test.

\section{Results}

In healthy men, compared with patients, lower values were found for:

shoulder girth in a tense state $(33.23 \pm 2.84)$ compared

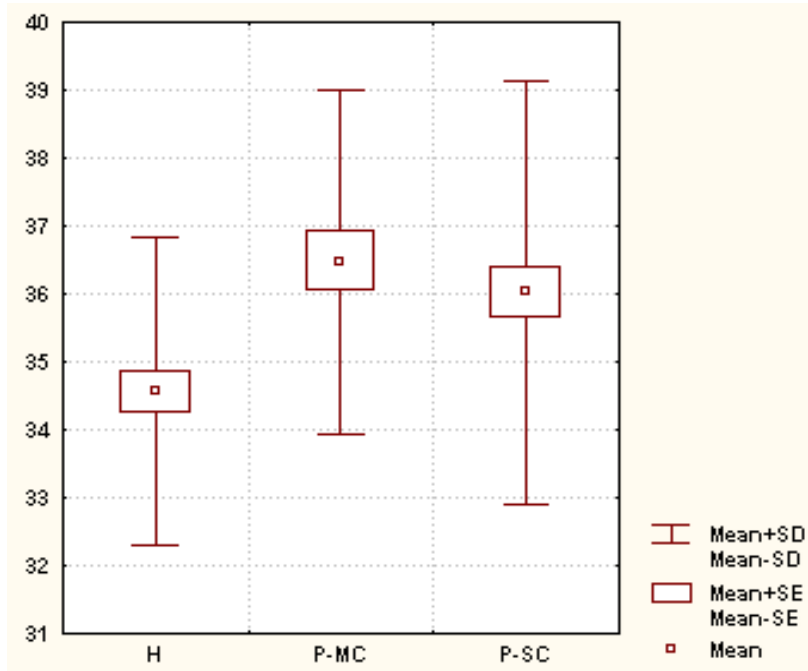

Fig. 1. Shoulder girth in stressed state in healthy and psoriatic men without taking into account somatotype $(\mathrm{cm})$. In this and similar figures in this section: $\mathrm{H}$ - healthy men; $\mathrm{P}-\mathrm{MC}$ - men with mild course of psoriasis; P-SC - men with severe course of psoriasis; Mean - average value; Mean $\pm S E$ - average value \pm error average; Mean $\pm S D$ - average value \pm standard deviation. 


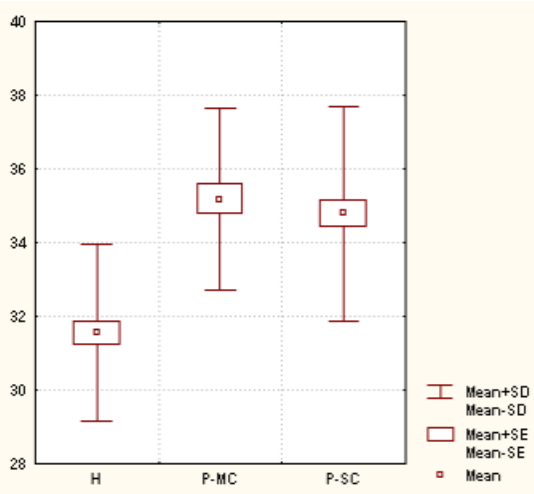

Fig. 2. Shoulder girth in non-stressed state in healthy and psoriatic men without taking into account somatotype $(\mathrm{cm})$.

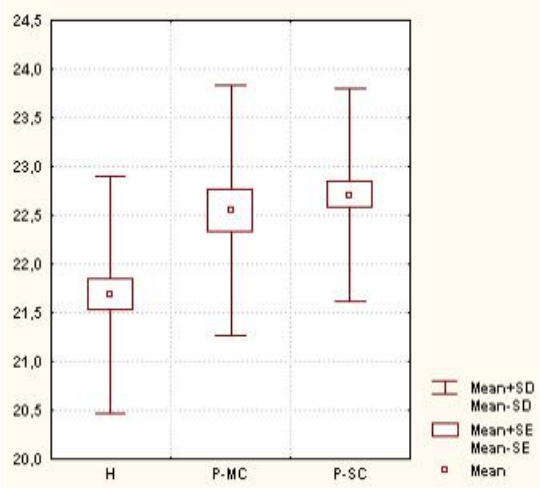

Fig. 5. Wrist girth in healthy and psoriatic men without taking into account somatotype (cm).

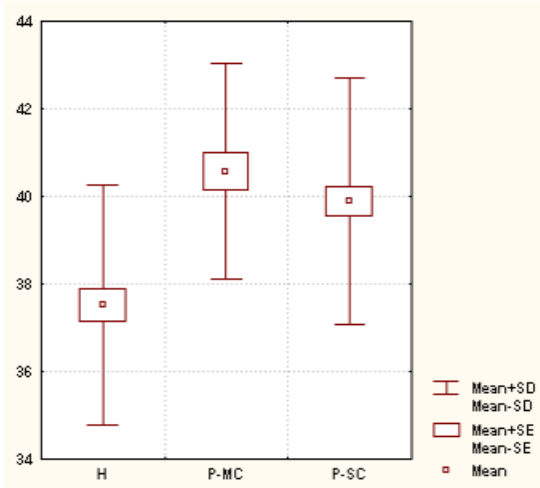

Fig. 8. Crus circumference in the upper part in healthy and psoriatic men without taking into account somatotype $(\mathrm{cm})$.

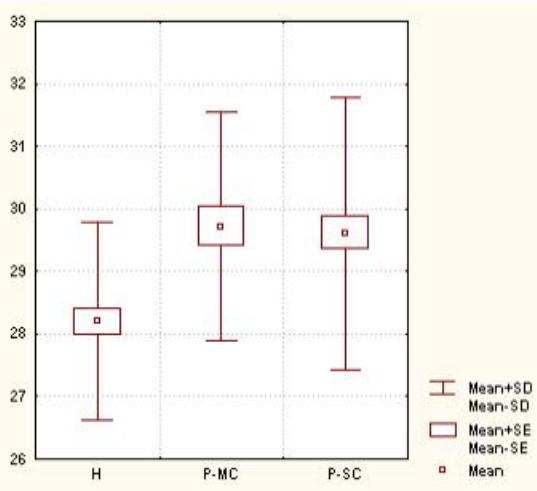

Fig. 3. Forearm girth in the upper part in healthy and psoriatic men without taking into account somatotype $(\mathrm{cm})$.
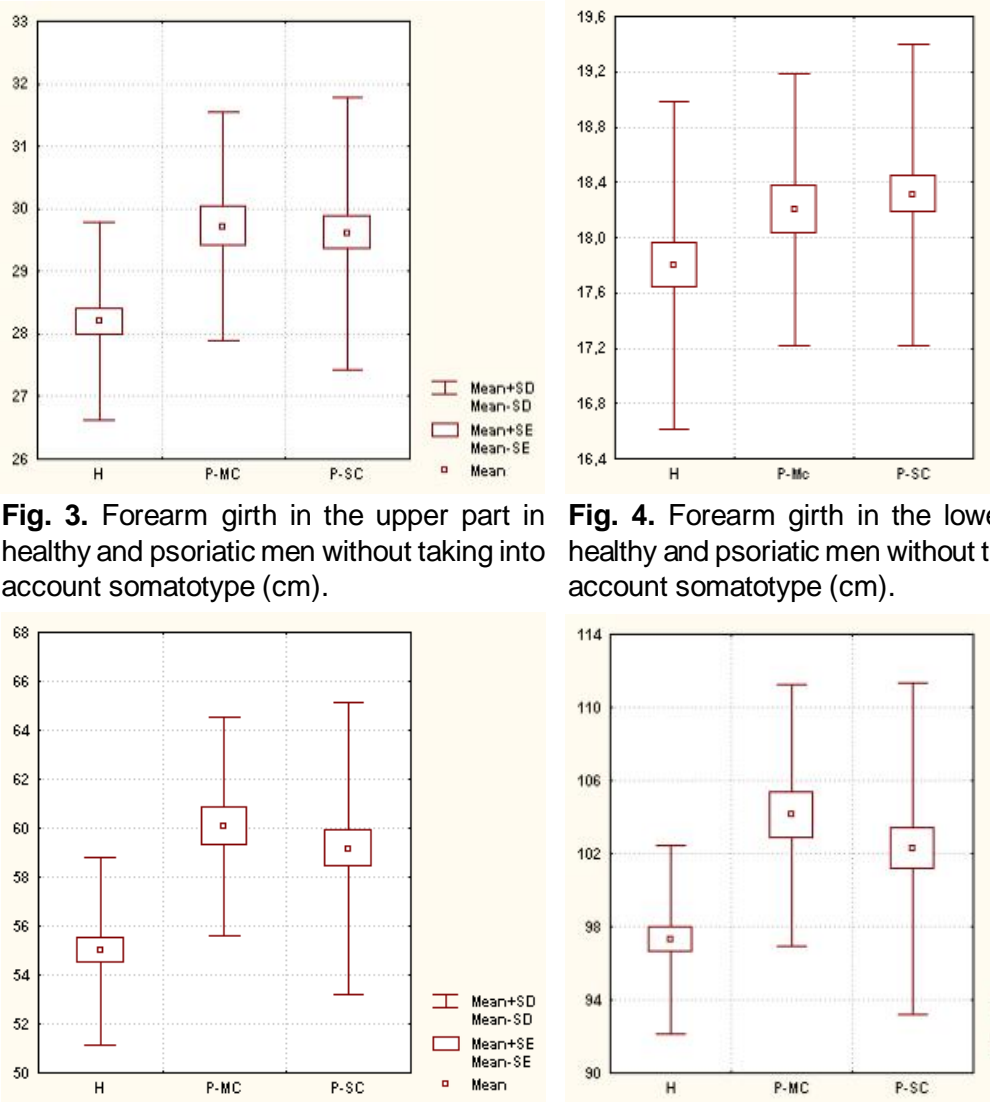

工 Mean+SD $\square$ Mean+SE

Fig. 4. Forearm girth in the lower part in healthy and psoriatic men without taking into account somatotype $(\mathrm{cm})$.

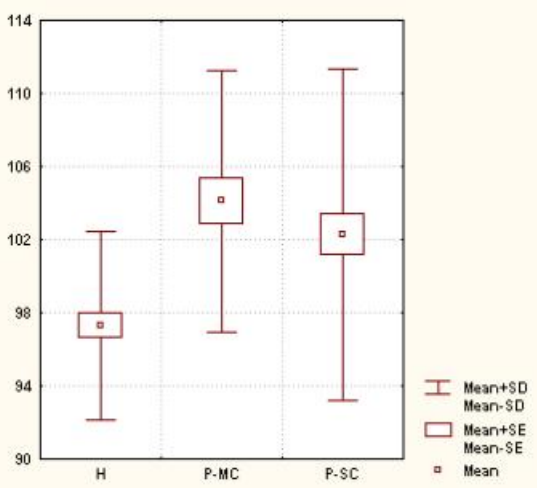

Fig. 6. Hip girth in healthy and psoriatic men Fig. 7. Hips girth in healthy and psoriatic men without taking into account somatotype $(\mathrm{cm})$. without taking into account somatotype $(\mathrm{cm})$.
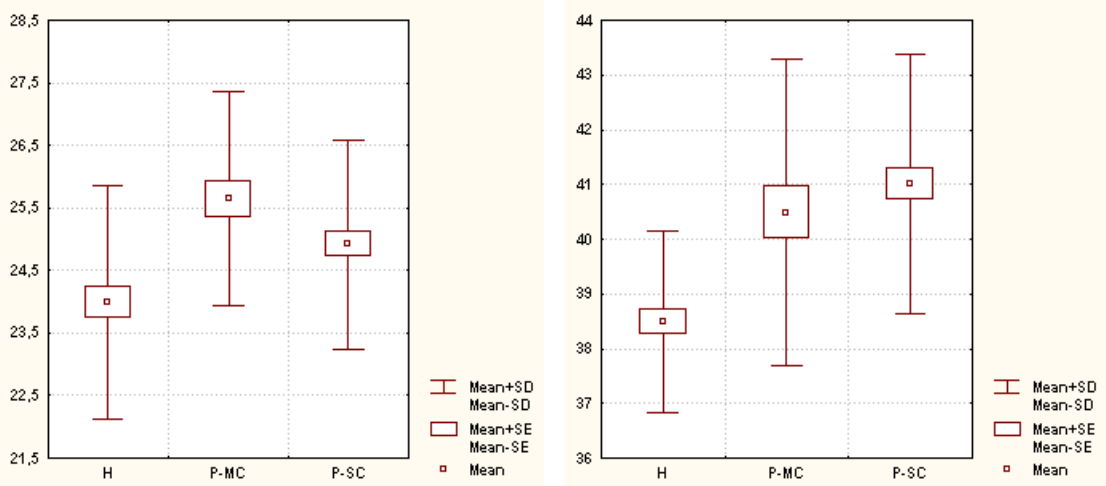

Fig. 9. Crus circumference in the lower part Fig. 10. Neck girth in healthy and psoriatic in healthy and psoriatic men without taking men without taking into account somatotype into account somatotype $(\mathrm{cm})$. with men with mild psoriasis $(36.47 \pm 2.54 ; \mathrm{p}<0.001)$ and severe psoriasis $(35.67 \pm 3.34 ; \mathrm{p}<0.001)$ (Fig. 1);

shoulder girth in a relaxed state $(30.17 \pm 2.94)$ compared with men with psoriasis of mild $(35.17 \pm 2.47 ; \mathrm{p}<0.001)$ and severe course $(34.41 \pm 3.19 ; p<0.001)$ (Fig. 2);

forearm girth in the upper part $(27.33 \pm 2.01)$ compared with men with mild psoriasis $(29.72 \pm 1.84 ; p<0.001)$ and severe psoriasis $(29.41 \pm 2.26$; $p<0.001)$ (Fig. 3);

forearm girth in the lower part $(17.44 \pm 1.24)$ compared with men with mild psoriasis $(18.20 \pm 0.98 ; p<0.01)$ and severe psoriasis $(18.27 \pm 1.10 ; p<0.001)$ (Fig. 4);

wrist circumference $(21.39 \pm 1.22)$ compared with men with mild psoriasis $(22.55 \pm 1.28 ; \mathrm{p}<0.001)$ and severe psoriasis (22.70 \pm 1.09 ; $\mathrm{p}<0.001$ ) (Fig. 5);

hip circumference $(53.25 \pm 4.49)$ compared with men with mild psoriasis $(60.08 \pm 4.45 ; \mathrm{p}<0.001)$ and severe

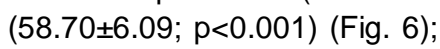

hips circumference $(95.04 \pm 6.39)$ compared with men 


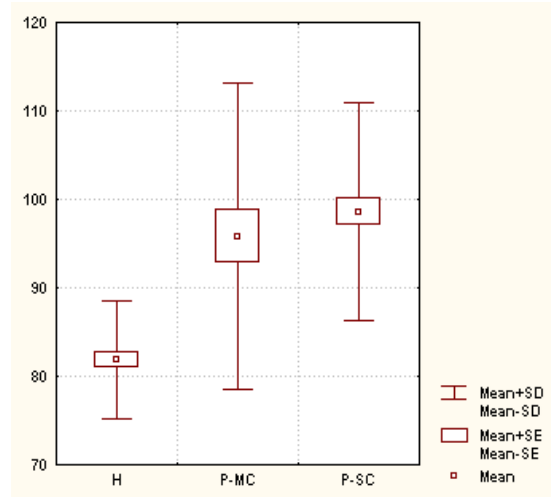

Fig. 11. Waist circumference in healthy and psoriatic men without taking into account somatotype $(\mathrm{cm})$.

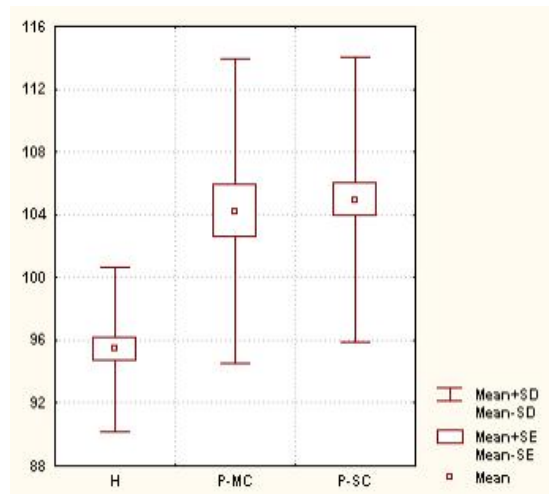

Fig. 13. Chest girth on exhalation in healthy and psoriatic men without taking into account somatotype $(\mathrm{cm})$.

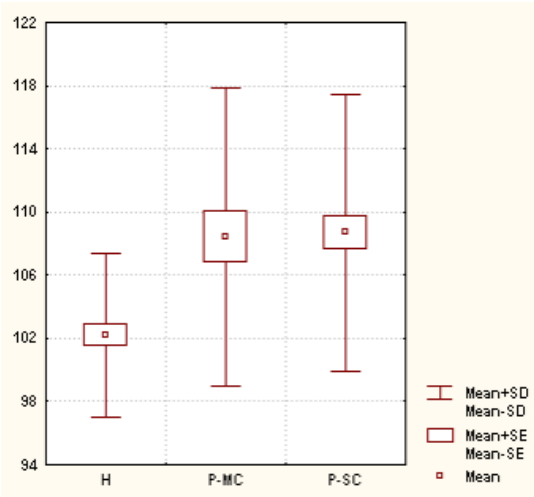

Fig. 12. Chest girth on inspiration and in healthy and psoriatic men without taking into account somatotype $(\mathrm{cm})$.

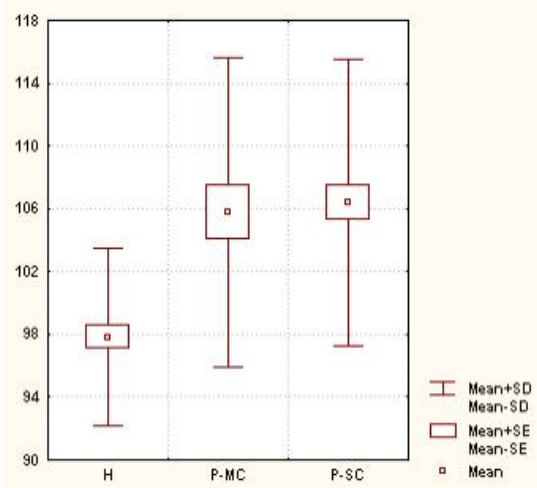

patients with severe psoriasis found greater values only of the girth of the crus in lower part $(25.64 \pm 1.71 ; 24.88 \pm 1.65$; $p<0.05$ ) (see Fig. 9).

\section{Discussion}

Given the most frequent manifestation of psoriasis at a young working age and in some cases severe, continuously recurrent course, the presence of many treatments, none of which is a guarantee of complete recovery and no recurrence - now there is an urgent need to find prognostic signs therapy and prevention of relapses [16].

In the absence of ideal biomarkers, the study of constitutional markers becomes crucial. Currently, there is a growing interest in comparing the somatotypological features of the organism in terms of normal and pathology. In this direction both anthropometric characteristics of a human body as a whole, and their separate features are investigated. The use of this area in the practical work of the doctor allows for a holistic and personalized approach in the process

Fig. 14. Chest girth at rest in healthy and of diagnosis and treatment $[17,23]$.

psoriatic men without taking into account somatotype $(\mathrm{cm})$.

In patients with psoriasis, a significant multiplicative interaction was found between $\mathrm{BMI}$, waist circumference

with mild psoriasis $(104.1 \pm 7.1 ; p<0.001)$ and severe psoriasis $(101.6 \pm 9.2 ; p<0.001)$ (Fig. 7);

crus girth in the upper part $(36.43 \pm 2.91)$ compared with men with mild psoriasis $(40.56 \pm 2.47 ; p<0.001)$ and severe psoriasis (39.55 $\pm 3.05 ; p<0.001$ ) (Fig. 8);

crus girth in the lower part $(23.41 \pm 1.87)$ compared with men with mild psoriasis $(25.64 \pm 1.71 ; p<0.001)$ and severe psoriasis (24.88 $\pm 1.65 ; p<0.001$ ) (Fig. 9);

neck circumference $(37.67 \pm 1.92)$ compared with men with mild psoriasis $(40.48 \pm 2.80 ; p<0.001)$ and severe (40.85 $\pm 2.38 ; p<0.001)$ (Fig. 10);

waist circumference $(79.48 \pm 7.32)$ compared with men with mild psoriasis $(95.83 \pm 17.27 ; \mathrm{p}<0.001)$ and severe psoriasis (97.18 $\pm 13.31 ; p<0.001)$ (Fig. 11);

chest girth on inspiration $(100.0 \pm 6.0)$ compared with men with psoriasis of mild $(108.4 \pm 9.4 ; p<0.001)$ and severe (107.8 $\pm 9.4 ; p<0.001)$ (Fig. 12);

chest girth on exhalation $(93.18 \pm 6.39)$ compared with men with mild psoriasis $(104.2 \pm 9.7 ; p<0.001)$ and severe psoriasis (103.9 $\pm 9.8 ; p<0.001)$ (Fig. 13);

chest girth at rest $(95.20 \pm 6.57)$ compared with men with mild psoriasis $(105.8 \pm 9.9 ; p<0.001)$ and severe psoriasis (105.3 $\pm 9.8 ; p<0.001)$ (Fig. 14).

In patients men with mild psoriasis compared with and two SNPs in the IL12B (rs3212227) and IL23R (rs7530511) genes [15]. It has been established that increased body mass index and increased waist circumference are risk factors for psoriasis. The association has been documented consistently in both case studies and cohort studies. Larger waist circumference, hip circumference, and waist-hip ratio were associated with a higher risk of psoriasis [7].

Recent studies have shown a positive and strong, compared to body mass index, correlation between abdominal girth and disease severity [1]. Sandeep Kumar et al. [12] found a direct stepwise correlation between body mass index, waist and hip circumference, and the risk of psoriasis in 67,300 women over a 12-year period.

A team of researchers led by E. Toussirot [25] and A.R. Setty [20] determined that the waist and hip circumference was higher in patients with psoriasis compared with the control group. S.V. Dmitrenko [5] in men with widespread psoriasis on the background of a decrease in the girth of the extremities found multidirectional changes in the girth sizes of the body.

The data obtained by us confirm the information provided by the authors about the predominance of the girth size of the limbs and torso in patients studied in comparison with 
the control group. The data were checked by the authors in the analysis of different age and ethnic groups.

In sick men in comparison with healthy we found higher values for - shoulder girth in a tense state by $8.9 \%$ and $6.8 \%$; shoulder girth in the unstressed state by $14.2 \%$ and $12.3 \%$; forearm girth in the upper part by $8.0 \%$ and $7.1 \%$; forearm girth in the lower part by $4.2 \%$ and $4.5 \%$; hand girth by $5.1 \%$ and $5.8 \%$; hip circumference by $11.4 \%$ and $9.3 \%$; hips circumference by $8.7 \%$ and $6.5 \%$; crus girth in the upper part by $10.2 \%$ and $7.9 \%$; crus girth in the lower part by $8.7 \%$ and $5.9 \%$; neck girth by $6.9 \%$ and $7.8 \%$; waist circumference by $17.1 \%$ and $18.2 \%$; chest girth on inspiration by $7.8 \%$ and $7.2 \%$; chest girth on exhalation by $10.6 \%$ and $10.3 \%$; chest girth at rest by $10.0 \%$ and $9.6 \%$ compared with men with psoriasis of mild and severe course.

\section{References}

[1] Augustin, M., Kruger, K., Radtke, M. A., Schwippl, I., \& Reich, K. (2008). Disease severity, quality of life and health care in plaque-type psoriasis: a multicenter cross-sectional study in Germany. Dermatology, 216(4), 366-372. doi: 10.1159/ 000119415

[2] Becker, L., Tom, W. L., Eshagh, K., Benjamin, L. T., \& Paller, A. S. (2014). Excess adiposity preceding pediatric psoriasis. JAMA Dermatology, 150(5), 573-574. doi: 10.1001/ jamadermatol.2014.324

[3] Bunak, V. V. (1941). Anthropometry. M.: People's Commissariat of the RSFSR.

[4] Chahoud, J., Semaan, A., Chen, Y., Cao, M., Rieber, A. G., Rady, P., \& Tyring, S. K. (2016). Association Between Pediatric Psoriasis and Waist-to-Height Ratio in the Absence of Obesity: A Multicenter Australian Study. JAMA Dermatology, 152(12), 1354-1364.

[5] Dmitrenko, S. V. (2008). Peculiarities of the body structure of Podillya residents suffering from various forms of psoriasis. Reports of Vinnytsia National Medical University, 12(1), 7579.

[6] Dogra, S., \& Mahajan, R. (2016). Psoriasis: Epidemiology, clinical features, co-morbidities, and clinical scoring. Indian dermatology online journal, 7(6), 471-480. doi: 10.4103/22295178.193906

[7] Duarte, G. V., \& Silva, L. P. D. (2014). Correlation between psoriasis' severity and waist-to-height ratio. Anais Brasileiros de Dermatologia, 89(5), 846-847. doi: 10.1590/abd18064841.20142854

[8] Ferguson, L. D., Brown, R., Celis-Morales, C., Welsh, P., Lyall, D. M., Pell, J. P., ... Sattar, N. (2019). Association of central adiposity with psoriasis, psoriatic arthritis and rheumatoid arthritis: a cross-sectional study of the UK Biobank. Rheumatology, 58(12), 2137-2142. doi: 10.1093/rheumatology/ kez192

[9] Fredriksson, T., \& Pettersson, U. (1978). Severe psoriasis - oral therapy with a new retinoid. Dermatology, 157(4), 238-244. doi: $10.1159 / 000250839$

[10] Griffiths, C., van der Walt, J. M., Ashcroft, D. M., Flohr, C., Naldi, L., Nijsten, T., \& Augustin, M. (2017). The global state of psoriasis disease epidemiology: A workshop report. British Journal of Dermatology, 177(1), e4-e7. doi: 10.1111/bjd. 15610

[11] Gutmark-Little, I., \& Shah, K. N. (2015). Obesity and the metabolic syndrome in pediatric psoriasis. Clinics in Dermatology, 33(3), 305-315. doi: 10.1016/j.clindermatol.2014.12.006
In patients with mild psoriasis course, compared with patients with severe psoriasis, only the crus girth in lower part was found to be higher by $3.1 \%$.

Thus, the comparison of the girth body size in healthy and patients with psoriasis of varying severity of men allowed to formulate criteria for risk and unfavorable prognosis of the psoriatic process.

\section{Conclusions}

1. In men with mild and severe psoriasis course, all body circumferences (except foot circumference) are larger than in healthy subjects.

2. In patients men with mild psoriasis course, compared with severe psoriasis course, higher values were found only for the girth of the lower crus part.

[12] Kumar, S., Han, J., Li, T., \& Qureshi, A. A. (2013). Obesity, waist circumference, weight change and the risk of psoriasis in US women. Journal of the European Academy of Dermatology and Venereology, 27(10), 1293-1298. doi: 10.1111/jdv. 12001

[13] Lee, A., Smith, S. D., Hong, E., Garnett, S., \& Fischer, G. (2016). Association between pediatric psoriasis and Waistto-Height ratio in the absence of obesity: a multicenter Australian study. JAMA Dermatology, 152(12), 1314-1319. doi: 10.1001/jamadermatol.2013.1078

[14] Li, R. C., Krishnamoorthy, P., DerOhannessian, S., Doveikis, J., Wilcox, M., Thomas, P., ... \& Mehta, N. N. (2014). Psoriasis is associated with decreased plasma adiponectin levels independently of cardiometabolic risk factors. Clinical and Experimental Dermatology, 39(1), 19-24. doi: 10.1111/ ced. 12250

[15] Li, W. Q., Han, J. L., Zhang, M. F., \& Qureshi, A. A. (2013). Interactions between adiposity and genetic polymorphisms on the risk of psoriasis. British Journal of Dermatology, 168(3), 639-642. doi: 10.1111/bjd.12001

[16] Nikolashina, O. E., \& Bakulev, A. L. (2015). On the relationship of congenital and adaptive immunity in psoriasis. Saratov Journal of Medical Scientific Research, 11(3), 421-423.

[17] Ozkaya, D. B., Onsun, N., Topukcu, B., Su, O., Bahal?, A. G., Dizman, D., ... Uysal, O. (2016). The relationship between body mass index, waist circumference and psoriatic arthritis in the Turkish population. Advances in Dermatology and Allergology / Postepy Dermatologii i Alergologii, 33(3), 219223. doi: 10.5114 /ada.2016.60615

[18] Parisi, R., Symmons, D. P., Griffiths, C. E., \& Ashcroft, D. M. (2013). Global epidemiology of psoriasis: a systematic review of incidence and prevalence. Journal of Investigative Dermatology, 133(2), 377-385. doi: 10.1038/jid.2012.339

[19] Phan, K., Lee, G., \& Fischer, G. (2020). Pediatric psoriasis and association with cardiovascular and metabolic comorbidities: Systematic review and meta-analysis. Pediatric Dermatology, 37(4), 661-669. doi: 10.1111/pde.14208

[20] Setty, A. R., Curhan, G., \& Choi, H. K. (2007). Obesity, waist circumference, weight change, and the risk of psoriasis in women: Nurses' Health Study II. Archives of Internal Medicine, 167(15), 1670-1675. doi: 10.1001/archinte.167.15.1670

[21] Snekvik, I., Nilsen, T. I. L., Romundstad, P. R., \& Saunes, M. (2019). Metabolic syndrome and risk of incident psoriasis: prospective data from the HUNT Study, Norway. British Journal 
of Dermatology, 180(1), 94-99. doi: 10.1111/bjd.16885

[22] Snekvik, I., Smith, C. H., Nilsen, T. I., Langan, S. M., Modalsli, E. H., Romundstad, P. R., \& Saunes, M. (2017). Obesity, waist circumference, weight change, and risk of incident psoriasis: prospective data from the HUNT study. Journal of Investigative Dermatology, 137(12), 2484-2490. doi: 10.1016/ j.jid.2017.07.822

[23] Tobin, A. M., Hackett, C. B., Rogers, S., Collins, P., \& Richards, H. L. (2014). Body mass index, waist circumference and HOMA-IR correlate with the Psoriasis Area and Severity Index in patients with psoriasis receiving phototherapy. British Journal of Dermatology (1951), 171(2), 436-438. doi: 10.1111/ bjd. 12914

[24] Torres, T., Machado, S., Mendonca, D., \& Selores, M. (2014). Cardiovascular comorbidities in childhood psoriasis. European Journal of Dermatology, 24(2), 229-235. doi: 10.1684/ ejd.2014.2291

[25] Toussirot, E., Aubin, F., Desmarets, M., Wendling, D., Auge, B., Gillard, J., ... Dumoulin, G. (2020). SAT0441 Body composition and fat distribution in patients with psoriasis or psoriatic arthritis. Annals of the Rheumatic Diseases, 79, 1177. doi: 10.1136/annrheumdis-2020-eular.2611

[26] Uczniak, S., Gerlicz, Z. A., Kozlowska, M., \& Kaszuba, A. (2016). Presence of selected metabolic syndrome components in patients with psoriasis vulgaris. Advances in Dermatology and Allergology/Postepy Dermatologii i Alergologii, 33(2), 114-119. doi: 10.5114/ada.2016.59153

[27] Zindanci, I., Albayrak, O., Kavala, M., Kocaturk, E., Can, B., Sudogan, S., \& Koc, M. (2012). Prevalence of metabolic syndrome in patients with psoriasis. The Scientific World Journal, 2012, 312463. doi: 10.1100/2012/312463

\section{ОСОБЛИВОСТІ ОБХВАТНИХ РОЗМІРІВ ТІЛА У ЧОЛОВІКІВ ХВОРИХ НА ПСОРІАЗ ЛЕГКОГО ТА ТЯЖКОГО ПЕРЕБІГУ}

\section{Обадех Бассам Абдель-Рахман Аль-Каралех, Дмитренко С.В., Шаюк А.В., Гунас І.В., Прокопенко С.В.}

З огляду на найбільш часту маніфрестацію псоріазу в молодому працездатному віці та в ряді випадків важкий, безперервно рецидивуючий перебіг, наявність безлічі методів лікування, жоден з яких не є гарантією повного одужання $і$ відсутності рецидивування, наразі виникла нагальна необхідність пошуку прогностичних ознак, необхідних для корекції терапії та профрілактики рецидивів. За відсутності ідеальних біомаркерів, дослідження конституціональних маркерів стає вирішальним. Мета дослідження - вивчити відмінності обхватних розмірів тіла між здоровими та/або хворими на псоріаз чоловіками в залежності від тяжкості перебігу захворювання. 32 чоловікам першого зрілого віку, хворим із легким перебігом і 68 із тяжким перебігом псоріазу проведено антропометричне обстеження за Бунаком. Для клінічної оцінки важкості перебігу $i$ площі псоріатичних уражень використали індекс PASI. Контрольну, за антропометричними параметрами, групу складали 82 практично здорових чоловіки аналогічного віку, відібрані з банку даних науково-дослідного центру Вінницького національного медичного університету ім. М. І. Пирогова. Статистичну обробку даних проведено в ліцензійному пакеті "Statistica 5.5" із використанням непараметричних методів оцінки отриманих результатів. У хворих на псоріаз легкого та тяжкого перебігу чоловіків, порівняно зі здоровими, нами встановлено: більші значення - обхвату плеча у напруженому стані на 8,9\% і 6,8\%; обхвату плеча у ненапруженому стані на 14,2\% і 12,3\%; обхвату передпліччя у верхній частині на 8,0\% і 7,1\%; обхвату передпліччя у нижній частині на 4,2\% і 4,5\%; обхвату кисті на 5,1\% і 5,8\%; обхвату стегна на 11,4\% і 9,3\%; обхвату стегон на 8,7\% і 6,5\%; обхвату гомілки у верхній частині на 10,2\% і 7,9\%; обхвату гомілки у нижній частині на 8,7\% і 5,9\%; обхвату шиї на 6,9\% і 7,8\%; обхвату талії на 17,1\% і 18,2\%; обхвату грудної клітки на вдиху на 7,8\% і 7,2\%; обхвату грудної клітки на видиху на 10,6\% і 10,3\%; обхвату грудної клітки у спокійному стані на 10,0\% і 9,6\%. Таким чином, виявлені виражені відмінності обхватних розмірів між здоровими і хворими на псоріаз легкого та тяжкого перебігу українськими чоловіками першого зрілого віку. Між хворими з різними ступенями важкості дерматозу відмінності встановлені лише для обхвату гомілки у нижній частині.

Ключові слова: псоріаз, обхватні розміри тіла, чоловіки. 